MONIKA WOŹNIAK, KAROLINA JESIEŃ,

ADAM KLEWENHAGEN

\title{
Rethinking Marxism with Ernst Bloch
}

Since the 1970s, a neo-liberal paralysis of political imagination has maintained a tight grip on many leftist thinkers and social activists. While the 2008 crisis once again proved capitalism's suicidal tendencies to be ineradicable, the global response to it seems to have been far from hopeful for the left. This is especially true in the wake of Brexit, Trump, Bolsonaro and Johnson, as well as many grassroot neo-fascist movements which have been steadily on the rise across Europe in the last decades. As Mark Fisher wrote, "capitalism seamlessly occupies the horizons of the thinkable" (Fisher 2013, 8). It is not coincidental that this sentence was published a year after the 2008 banking crisis, which has as yet failed to ignite a revolutionary sparkle. However, perhaps refuting, Fisher's over-fatalistic predictions to some extent, recently there has been a significant rise of feminist and ecologically oriented grassroot movements. This has undoubtedly sparked new hopes for a possibility of an alternative to the capitalist Now, however proposals for a radical change of the mode of production are still very rare. As a possibly hopeful contribution to this debate, we propose turning to the almost century-old prolific writings of Ernst Bloch and, in particular, his concept of utopia.

Ernst Bloch's oeuvre spreads over more than five decades, stretching far beyond the turbulent and heavily periodized "age of catastrophe" (1914-1945). Nevertheless, from his first book publication - The Spirit of Utopia (1918/23) - to the gigantic opus magnum of The Principle of 
Hope (1954-59, written between 1938 and 1947), Bloch's focal point of interest seems to circle around one issue in particular: he guides us into thinking utopia immanently, as a Not-Yet (Noch-nicht-Gewordene) that is to come from within. That is, thinking utopia firstly from within the historical "Now", as encapsulated asynchronies with the capitalist order (Heritage of our Times, 1935). Secondly, thinking it from within the subject and the "subjective" aspect of society such as culture, art, religion (The Spirit of Utopia). Finally, from within real possibilities of changing society. In this last instance Bloch offers us the notion of a "concrete utopia" - one, which does not abide by the rules of realpolitik and yet channels a possibility of something radically different (The Principle of Hope).

The contemporary significance of Bloch's thought, however, can be noticed not only in how his concept of concrete utopia enriched Marxism with "warmer", more subjective elements (a supplement to "colder" socioeconomic strategies). The two most prominent ideas, which proved useful for contemporary Marxist scholarship, are his theory of non-synchronism and his analysis of fascism. For example, Bloch's idea of Ungleichzeitigkeit has been used to combine Marxist philosophy of history with a postcolonial perspective in Massimiliano Tomba's Marx's Temporalities. Tomba argues that the non-simultaneous character of capitalism is, in fact, an essential factor for the production of surplus value. According to Tomba, global capital benefits from "temporal" differences between the center and peripheries, "synchronizing" them through hegemonic socially necessary labour time (e.g. Tomba 2013, xiii). Bloch's concept of multi-temporal dialectics can therefore be employed by Marxism as a tool against the progressivist perspective of history and simplified stage-theory of development.

The theory of non-synchronism is also at the centre of Bloch's writings on fascism. In The Heritage of Our Times he explains in a compelling way that fascism was able to exploit the sentiments arising from contradictions between older and more modern forms of living and production. In this light, his analysis of temporal contradictions allows us to see the positive element behind every far-right project: a longing for something better. Therefore, Bloch indicates the possibilities of harnessing the irrational mythic elements at work behind fascism for the crucial conflict of labour and capital. As Anson Rabinbach puts it, Bloch "not only attempts to reveal the fertile and productive soil from which these ideas emerged, but he is concerned with them as an unclaimed radical heritage passed by the Left in its abstract critique of the illusory and 'false consciousness"' (Rabinbach 1977, 11). We want to read this 
gesture as a political stance for today that does not simply view the voters of the far-right from the pedestal of liberal contempt, but instead tries to understand the mechanisms behind their decisions and reclaim their origins. The same approach was applied by Bloch - and could continue to be applied by the radical Left today - to religion and religious movements.

It is especially significant for the publication of this issue, originating in Poland, that Bloch's analysis of fascism seems to respond to the very problem found in many of the outlooks on the current rise of far right. Namely, that the contemporary diagnoses of populism as well as those of structural fascism seem to either treat this global tendency as an undifferentiated universal phenomenon, or focus on the specificity of the local context (be it Italian, German, or North American). Instead, what Bloch's non-synchronicity enables us to see are the intertwining entanglements of center-periphery relations. And while in the 1930s this was applied to Germany alone, in the times of globalized capitalism we should take Bloch's analysis a step further and view fascism in the light of world-market dependencies rather than simply nationalistic tendencies contained within the borders of various separate countries.

Moreover, we believe that reading Bloch today can address the problems associated with Marxists theories appealing to the communist aspect of what is already present. This is the case with, for example, Hardt and Negri's sublation of the difference between the capitalist temporality of the present and revolutionary, proletarian temporality oriented toward the future. In a polemical reference to Bloch's future-oriented philosophy, with its complex relation to the present, they argue for a more immediate understanding of the encapsulated utopias in the now. "Today", they write, "revolution is no longer imaginable as an event separated from us in the future but has to live in the present, an 'exceeding' present that in some sense already contains the future within it" (Hardt and Negri 2009, 242). Such an equation of Bloch's theory of hope with an image of revolution as separated from us in the future is, however, ambiguous. The orientation towards "pure immanence", which they propose against such a presentation of Bloch's ideas, can limit our imagination of emancipation to strategies, tactics and forms of life already determined by the current, capitalist mode of production. We believe that Bloch's temporality of hope for a different future offers answers to the shortcomings of the philosophy of immanence of this sort. It is his notion of the Not-Yet, associated with a concrete utopia that allows for radical hope, rather than only immanent hope. That is - hope for a revolutionary rupture in the course of history is possible due to the current
And while in the 1930s

this was applied to

Germany alone, in the

times of globalized

capitalism we should

take Bloch's analysis a

step further and view

fascism in the light of

world-market depen-

dencies rather than sim-

ply nationalistic tenden-

cies contained within

the borders of various

separate countries. 
While immanent hope may pacify utopian desires by promising that the future is somehow already present, the Blochian radical hope of the Not-Yet animates them by identifying current possibili-

ties as ways out toward the Future. conditions, but it is by no means limited in its form to what these conditions dictate. While immanent hope may pacify utopian desires by promising that the future is somehow already present, the Blochian radical hope of the Not-Yet animates them by identifying current possibilities as ways out toward the Future.

The texts presented in the issue adopt a mixed approach to Bloch's philosophy. Some of the authors discuss the philosophical roots of Bloch's project and point to its historical context. Cat Moir offers an insight into the biocentric inspirations behind Bloch's early writings, while Lucien Pelletier critically reconstructs Bloch's moral theory in its historical development, emphasising links with the thought of Georg Simmel and Max Scheler. Loren Goldman traces Bloch's materialism by situating the problem of the ontological grounds for revolutionary praxis in the historical context of the Aristotelian and Hegelian left, and by juxtaposing Bloch and Althusser's materialisms.

Other authors focus on locating Bloch's thought within the discussions important for the contemporary Left. Jan Rehmann argues for a praxis-oriented reading of Bloch's philosophy and offers an ecological reading od Bloch, with a fruitful comparison of Bloch's concept of anticipation and hope with Gramsci's philosophy. Dritëro Demjaha discusses Ernst Bloch's notion of 'meta-religion' and examines his reassessment of religion and Hegel's idealism, arguing that they are intrinsically linked in Bloch's thought, as two sources of Marxism similar in their limits and contributions. Federico Filauri, in his analysis of Messianic temporalities in Agamben and Bloch, shows the latter's future-oriented philosophy as the answer to the aporiae of politics based on subtraction. Felipe Catalani discusses the problem of anticipatory thinking as phantasy in its two opposing dimensions: utopian, represented by Bloch, and catastrophist, associated with Günther Anders. Sebastian Truskolaski reconstructs Bloch and Adorno's discussion on utopia and warns against the over-determination of our images of the future.

An important factor for our publication is the limited scholarship on Bloch available for the Polish reader. There is only one monograph on Bloch in Polish (Anna Czajka, "Człowiek znaczy nadzieja: o filozofii Ernesta Blocha”, 1991). Bloch's main works - apart from Spuren, also translated by Anna Czajka - are not yet available in Polish. We hope, therefore, that this issue will serve as an impulse to start discussion on 
Ernst Bloch in Polish scholarship, especially among more Marxist-oriented scholars.

\section{References}

Hardt, Michael and Negri, Antonio. 2009. Commonwealth. Cambridge, Massachusetts: The Belknap Press of Harvard University Press.

Tomba, Massimiliano. 2013. Marx's Temporalities. Translated by Peter D. Thomas and Sara R. Farris. Leiden/Boston: Brill.

Fisher, Mark. 2009. Capitalist Realism. Is There No Alternative?. Winchester: Zero Books.

Rabinbach, Anson. 1977. "Unclaimed Heritage: Ernst Bloch's Heritage of Our Times and the Theory of Fascism." New German Critique, No. 11: 5-21.

Citation: Woźniak, Monika; Jesień, Karolina and Klewenhagen, Adam. 2020. "Rethinking Marxism with Ernst Bloch". Praktyka Teoretyczna 1(35): 7-11.

DOI: $10.14746 /$ prt2020.1.1

Autor: Woźniak, Monika; Jesień, Karolina i Klewenhagen, Adam

Tytuł: Przemyśleć marksizm z Ernstem Blochem 